\title{
ПОЛИТИЧЕСКИЕ РЕПРЕССИИ В СРЕДНЕ-СПЕЦИАЛЬНОМ ОБРАЗОВАНИИ ЮЖНОГО УРАЛА В 1930-1934 ГОДАХ
}

\section{POLITICAL REPRESSION \\ IN THE SECONDARY SPECIAL EDUCATION \\ OF THE SOUTHERN URALS IN 1930-1934}

S. Semenov

Summary: In article on the basis of archival documents are considered state policy on a secondary special education in South Ural in 1930-1934. Mass repressions in technical schools, South Ural reflected all-union trends: "expelled" fists, their close and distant relatives, "Trotskyists" and their allies. As a result of political repression in the 30 s of the twentieth century, teachers with pre-revolutionary work experience were seriously affected in secondary special educational institutions in the Southern Urals.

Keywords: political repression, secondary special education, South Ural, technical schools.

\author{
Семенов Сергей Владимирович \\ К.и.н., доцент, Оренбургский \\ государственный университет \\ ssemenov_2001@mail.ru
}

Аннотация: В статье на основе архивных документов рассматриваются государственная политика в отношении средне-специального образования на Южном Урале в 1930-1934 гг. Массовые репрессии в техникумах, училищах, Южного Урала отражали общесоюзные тенденции: «изгоняли» кулаков, их близких и дальних родственников, «троцкистов» и их союзников. В результате политических репрессий в 30-тые годы XX века в средне-специальных учебных заведениях Южного Урала серьезно пострадали преподаватели с дореволюционном стажем работы.

Ключевые слова: политические репрессии, средне-специальное образование, Южный Урал, училища, техникумы.
$\mathrm{B}$ начале 30-х годов XX века важное значение для экономического развития Южного Урала приобретают средне-специальные учебные заведения. Именно на них возлагалось роль массовой подготовки специалистов для народного хозяйства региона. В данный процесс определенные коррективы вносила всеобщая идеологизация и политизация населения Южного Урала и страны. Мощное давление на народное образование объясняется желанием государством иметь контролируемую интеллигенцию. Несогласием с курсом ВКП(б) старой дореволюционной интеллигенции стало определяющим фактором в дальнейшей судьбе последней. Партия берет курс на изгнание из учебных заведений, а затем и физическое уничтожение преподавателей, студентов, служащих с так называемым не пролетарским происхождением. Это можно проиллюстрировать на материалах и Южно-Уральских средне-специальных учебных заведениях.

В октябре 1930 года начались занятия в Шадринском сельскохозяйственном техникуме птицеводства, где готовили специалистов для создаваемых птицеводческих колхозов и совхозов на Южном Урале. Студент техникума, успешно осваивающий тонкости ухода за птицей - это еще не означало успешное окончание средне специального учебного заведения. Определяющим фактором было пролетарское происхождение, всех остальных определяли как «чуждых элементов» и гнали везде прочь. Так студентов: Новоселова, Хлюпина (Хляпина), Машинина исключили из техникума. Молодые люди вы- сказывались о темпах коллективизации, считая их «непосильными», что соответствует исторической действительности, этот факт послужил основанием в обвинении в «уклоне от генеральной линии партии». После этого партийные органы техникума поставили задачу «не позволить распространиться подобному своемыслию, идущему от кулацкого влияния». Это послужило сигналом к тщательной проверке социального состава студентов техникума. В результате исключили как «чуждый элемент» еще двух студентов: Подкорытова и Симакова [19. C. 59-61].

С февраля по октябрь 1931 года длилось расследование по делу «Интеллектуального центра» в городе Шадринске. Оперативно-следственными мерами были установлены участники и организатор антисоветской группы - А.П. Лысенин - бывший ученик Шадринской школы ФЗС, из учащихся средне-специальных учебных заведений Шадринска «проводил вербовку», в результате по данным органов ОГПУ в состав вошли: Р.Н. Щинов, Л.С. Горин, В. Кобелев, Н. Гайнулин, А. Груздев - учащийся школы ФЗС, К.А. Таскаев, А.А. Авдюшев - учащийся медфака, А.П. Воротникова - студент педтехникума, В. Лавров - ученик механической мастерской тракторцентра, а собрания проводились в помещение Шадринского научного хранилища (Музей - С.С.), где работал еще один якобы участник антисоветской группы - В. Линденбаум хранитель музея [10. Л. 1-30].

Антисоветская деятельность «Интеллектуального 
центра» заключалась в следующем: в начале 1931 года В школе ФЗС на конференции по проработке итогов VI партийного съезда, некоторые ученики выступили в поддержку теории Н. Бухарина по крестьянскому вопросу, А.П. Лысенин - лидер группы позволил высказаться против быстрых темпов коллективизации, а также считал, что «некоторых кулаков можно перевоспитать», но правительство вело политику уничтожения кулачества как класса и увеличения темпов коллективизации. Таким образом, А.П. Лысенин выступал против генеральной линии партии, за что и был арестован. Необходимо отметить, что средний возраст участников так называемого «Интеллектуального центра» от 14 до 17 лет, а организатору антисоветской группы было 16 лет, но это не смутило уполномоченного Шадринского окружного отдела ГПУ - Васильева, занимавшегося расследованием, не вызвало это дело подозрения и у начальника Шадринского Райотделения ОГПУ Петрова, визировавшего дело для направления на «внесудебное рассмотрение тройки - ПП ОГПУ по Уралу». Бумаги отправили в Свердловск, а участники оставались в заключении в Шадринске. Здесь с руководителем группы произошел типичный случай: для выяснения намерений А.П. Лысенина была использована «подсидка», к нему в камеру поместили агента ОГПУ. Вскоре он сообщил, что А.П. Лысенин хочет бежать [10. Л. 76].

Вернемся к судьбе участников «Интеллектуального центра»: в октябре 1931 года из Свердловска - СПО ПП ОГПУ по Уралу была прислана бумага, где сообщалось следующее: «ввиду несовершеннолетия подавляющего большинства обвиняемых, полнейшего признания инициаторами группировки ошибочности своих прежних взглядов, раскаяния в их антисоветской деятельности...». По названым причинам особое совещание коллегии ОГПУ 7 октября 1931 года приняло решение дело в отношении Лысенина, Щипова и других 10 человек обвиняемых по статье 58 пунктам 10 и 11 УК РСФСР прекратить, людей из «под стражи освободить... дело отдать в архив расписки ануллировать». Таким образом, руководство ОГПУ по Уралу тщательно изучило материал дела и заключило, что «совершенно формально проведено следствие с установкой на применение репрессий» [9. Л. 205-205 об.].

В 1932 году в Чашинском молочном техникуме Курганского района Челябинской области органами ОГПУ (с 1934 года - НКВД) было арестовано три студента: К.С. Неволин, Г.П. Ефимов, К.И. Стрелков по обвинению к принадлежности к контрреволюционной организации.

По оперативным данным ОГПУ контрреволюционная группа возникла из учеников школы крестьянской молодежи (далее - ШКМ) и студентов молочного техникума села Чаши в 1931 году «на почве недовольства проводимыми мероприятиями Советской власти: коллективиза- ция, ликвидация кулачества как класса, хлебозаготовки, плохое снабжение учеников продовольствием». Группа состояла из 7 человек из них трое ученики ШКМ и столько же студентов молочного техникума, и один рабочий Чашинского ЛТХ - Д.Х. Зырянов определенный оперативными сотрудниками ОГПУ как руководитель контрреволюционной группы [7. Л. 92-98].

Коллегия ОГПУ по Уралу 21.09.1932 К.С. Неволина, К.И. Стрелкова признала виновными по статье 58 пункту 11 и приговорила к двум годам высылки в Северный край условно. По аналогичной статье и тому же пункту Г.П. Ефимов и Д.Х. Зырянов ОС ОГПУ по Уралу приговорены к лишению права проживания в 12 населенных пунктах Уральской области, «с прикреплением на 3 года, считая срок со дня вынесения постановления» [14. С. $298,323,343]$. Достаточно мягкий приговор можно объяснить следующим: еще не в полную силу репрессивная машина начала работать в сфере народного образования страны и Южного Урала.

В сентябре 1932 года на собрании педагогического коллектива Курганского промышленного техникума поручено заведующему учебной частью к 15 октября подготовить доклад «О методических извращениях» [2. Л. 1-6]. В начале 30-х годов XX века правительственные директивы о народном образовании требовали преподавать каждый предмет программы с точки зрения марксизма-ленинизма.

В октябре 1932 года ОО ПП ОГПУ по Уралу ликвидировала контрреволюционную повстанческую организацию в Мокроусовском, Белозерском, Курганском районах Уральской области (теперь районы Курганской области). Найденный руководитель Д.Г. Русаков был для ОГПУ весьма удобен по ряду обстоятельств. Во-первых, студент столичного вуза - Московского финансово-экономического института, во-вторых, социальное происхождение: его отца признали кулаком.

В данном случае Д.Г. Русаков в июле 1931 года приехал на студенческие каникулы, но, по сведениям ОГПУ, он прибыл с заданием от правооппортунистической антипартийной группы, якобы существовавшей тогда в Москве. Необходимо напомнить, что примерно в это время идет борьба с оппортунизмом в Москве. И, вероятно, на местах не хотели отставать от «модных тенденций» в разоблачении антисоветских групп.

Возвращаясь к изучению следственного дела на антисоветскую группу Д.Г. Русакова, следует отметить, что арестовано было 47 человек, а также ОГпУ поработала и над определением структуры организации: основных повстанческих групп «вскрыто» 7, из них две в Курганском районе, четыре в Мокроусовском и одна в Белозерском [5. Л. 268]. Рассмотрим подробно Дмитриевскую 
контрреволюционную группу. Она якобы состояла из 4 преподавателей ШКМ и 10 человек учащейся молодежи, лидером группы сотрудники ОГпУ определили преподавателя труда ШКМ Д.В. Симонова. Вина людей заключалась в том, что они высказывали свое мнение в отношении политики Советского правительства, в частности, они отмечали, что «политика коллективизации является политикой искусственного вмешательства в нормальный ход развития крестьянского хозяйства», а в отношении промышленности они подчеркивали, что «темпы взятые в деле индустриализации не посильны» [5. Л. 269-271]. В марте 1933 года коллегия ОГПУ рассмотрела дело о контрреволюционной повстанческой группе Д.Г. Русакова и постановила Д.Г. Русакова, Г.Н. Шадских, Д.В. Симонова направить в исправительно-трудовой лагерь на 10 лет, всем остальным участникам группы «зачесть в наказание срок предварительного заключения из-под стражи освободить» [6. Л. 389].

Аналогичная ситуация происходила и в Оренбургских средне-специальных учебных заведениях. Первого директора Оренбургского музыкального техникума А.В. Буздыханова уволили за недостаточное обеспечение в составе слушателей техникума детей с пролетарским происхождением, а затем приказ № 23 от 15 июня 1931 года конкретизировал борьбу против преподавателей с дореволюционным образованием: «Ввиду сохранения нижепоименованными педагогами старых академических и педагогических установок, а также отсутствия у таковых марксистского мировоззрения и не владения методом диалектического материализма товарищи А. Буздыханов, Л. Матковский, Е. Чубинская, М. Троицкая, В. Боголюбова, 3. Виноградова с 1931-1932 учебного года считаются освобождёнными, каковым надлежит не позднее 10 июня сего года сдать все учебники и учебные пособия и получить окон ᄀчательный расчёт» [18. С. 165].

Репрессивные меры нового руководства техникума коснулись не только преподавателей, но и студентов, которым запрещалось вводить современные жанры в киноиллюстрации. Так, приказ директора техникума С. Горбачёва от 21 марта 1931 года гласил: «Считаю совершенно недопустимым применение фокстрота, уан-степа и тому подобной синкопированной музыки в картинах русского революционного жанра, а потому предлагаю изъять из практики киноиллюстрации музыку типа нэпманского характера» [17. С. 329].

В декабре 1932 года СПО Челябинского оперсектора ОГПУ в селе Птичьем Шумихинского района Уральской области была ликвидирована очередная контрреволюционная организация - «Сельско-крестьянская партия». В стране идет процесс уничтожения кулачества как класса, значит, в каждом регионе страны его надо найти. Организатором ОГПУ провозгласило А.Е. Самбурского - учащегося ФЗУ при ЧГРЭС, но определяющим фак- тором, мы считаем, было наличие родного брата, осужденного за контрреволюцию и сосланного на Соловки. Да и состав «СКП» ОГПУ выявило следующий: «сыновья кулачества, родственники и друзья ранее осужденных за контрреволюционную деятельность» [8. Л. 250-258]. Результатом оперативно следственных действий ОГПУ стало включение в состав группы следующих учащихся ФЗУ при ЧГРЭС: И.А. Кожевникова, Г.А. Югова, Д.Н. Тимофикова, А.Н. Силиванюка, и определение цели и задачей «СКП», они выступали «против колхозного строительства и других мероприятий Советской власти» занимались подготовкой «вооруженного восстания для свержения Советской власти». Особое совещание при коллегии ОГПУ 9 июля 1933 года определила участникам «СКП» следующие наказания: А.Е. Самбурского - «выслать через ПП ОГПУ на 2 года», И.А. Кожевникову, Д.Н. Тимофикову, А.Н. Силиванюку - «зачесть в наказание срок предварительного заключения и из-под стражи освободить» [8. Л. 250-277-394].

В 1933 году Курганским оперативным сектором ОГПУ была ликвидирована «антисоветская группировка педагогов», в состав которой включили преподавателей ФЗС и Педтехникума города Кургана: Е.Г. Венявцев - преподаватель физики в Педагогическом техникуме, Ф.К. Новиков - преподавал русский язык и литературу, а также иностранный язык в ФЗУ связи в Кургане, организатор группы по данным ОС ОГПУ Кургана - А.В. Азясский - заведующий школой № 2 Кургана. В марте 1933 года всех участников этой якобы группировки обвинялись по 58 статье пунктам 10 и 11 УК РСФСР, а «мерой пресечения способов уклонения от следствия и суда» было избрано «содержание под стражей». Таким образом, на время следствия все участники находились в Курганском доме заключения. Антисоветская агитация выражалась в том, что педагоги позволили в кругу своих знакомых обсуждать проблему несвоевременной выдачи им зарплаты [4. Л. 12-63]. Фактически работникам средне-специального сектора народного образования города Кургана запрещалось высказывать мысли, которые могут навредить местным партийным функционерам.

В апреле 1933 года участникам антисоветской группы было предъявлено обвинение, в котором все «себя виновными признали». Следственное дело направили через СПО ПП ОГПУ по Уралу на внесудебное рассмотрение. В мае 1933 года начальнику Курганского ОС ПП ОГПУ пришла телеграмма за № 18527/4, где сообщалось: «Следственное дело...прекращено, предлагаем немедленно арестованных по делу освободить. Принимая во внимание, что у всех обвиняемых имеется большая семья; что обвинение построено на недостаточно веских материалах» [4. Л. 65]. Вышестоящие инстанции действительно объективно, еще пока, рассматривали следственные дела. Об этом свидетельствует и приведенная в телеграмме аргументация. 
В Куртамышском педагогическом техникуме особое внимание при приеме абитуриентов уделяли сначала «социально классовому лицу» и только потом проверяли способность учиться в средне-специальном учебном заведении, а за первый семестр 1933-1934 года исключено два студента как «классово-чуждые» [1. Л. 7, 10 об.].

В 1934 году в Троицком лесотехникуме Челябинской области три студента были обвинены в троцкизме [13. Л. 449 об.]. В 1934 году среди студентов Оренбургского башпедтехникума были ликвидированы контрреволюционные националистические группировки. Руководителем групп сочли И.3. Темирова. Его обвиняли в том, что он разжигал вражду к «русским, которые, втягивая их (башкир - С.С.) в учебу, хотят еще больше закабалить». И.3. Темиров за якобы «преступную» деятельность был исключен из комсомола. В вину ему ставился и тот факт, что, будучи у себя на родине в Сорочинском районе во время каникул, прислал товарищам письмо, в котором писал, что «колхозники голодают и надежды на улучшение положения нет...и никогда они не придут к зажиточной жизни». По этому делу было арестовано четыре человека. Какова была их дальнейшая судьба - неизвестно [15. C. 207].

В течение десяти месяцев просидели в тюрьме сту- денты Оренбургского железнодорожного техникума за «недовольство материальными условиями жизни работников путей сообщения» [16. С. 35].

Неспокойно было и в Бугурусланском сельскохозяйственном техникуме. Его директора - Шарапова К.Н. - обвинили в не принятии мер к «очищению и оздоровлению педколлектива». Партийные органы отмечали, что педагогический коллектив был «засорен чуждовраждебными элементами: И.П. Иванов - контрреволюционер, Архангельский - сын попа и другие» [11. Л. 11]. За этот проступок К.Н. Шарапову объявили строгий выговор с формулировкой «за переадминистрирование в руководстве техникума» [12. Л. 123 об.].

Массовые репрессии в техникумах, училищах, Южного Урала отражали общесоюзные тенденции, когда страна боролась с «кулачеством» из средне-специальных учебных заведений региона «изгоняли»: кулаков, их близких и дальних родственников. После убийства С.М. Кирова 1 декабря 1934 года во всех техникумах Южного Урала искали «троцкистов» и их союзников. В результате политических репрессий в 30-тые годы XX века в средне-специальных учебных заведениях Южного Урала серьезно пострадали преподаватели с дореволюционном стажем работы.

ЛИТЕРАТУРА

1. Государственный архив Курганской области (далее - ГАКО). Ф. Р-2239. Оп. 1. Д. 2.

2. ГАКО. Ф. Р-516. 0П. 1.Д. 3.

3. ГАОПДКО. Ф. 6905. Оп. 2. Д. 1086.

4. ГАОПДКО. Ф. 6905. Оп. 2. Д. 155.

5. ГАОПДКО. Ф. 6905. Оп. 2. Д. 2464.

6. ГАОПДКО. Ф. 6905. Оп. 2. Д. 2467.

7. ГАОПДКО. Ф. 6905. Оп. 2. Д. 4043.

8. ГАОПДКО. Ф. 6905. Оп. 2. Д. 4843.

9. Государственный архив общественно-политической документации Курганской области (далее - ГАОПДКО). Ф. 6905. Оп. 2. Д. 1085.

10. ГАОПДКО. Ф. 6905. Оп. 2. Д. 1086.

11. Объединенный государственный архив Оренбургской области (далее - ОГАО0). Ф. 1507. Оп. 1. Д. 28.

12. ОГАОО. Ф. 1256. ОП. 1. Д. 535.

13. Объединенный государственный архив Челябинской области (далее - ОГАЧ0). Ф. 2620. Оп. 1. Д. 1.

14. Осуждены по 58-й... Книга памяти жертв политических репрессий Курганской области. Т. 2. Курган: Зауралье, 2003. 384 с.

15. Футорянский Л.И. Репрессии 1927-1938 годов // Оренбург. Челябинск: Южно-Уральское книжное издательство, 1993. С. $204-213$.

16. Футорянский Л.И. Трагедию не предавать забвению // На защите интересов России. Губчека-УФСБ 80 лет / Научн. рук. Л.И. Футорянский. Оренбург: Оренбургская губерния, 1998. С. 25-45.

17. Хавторин Б.П. История музыкальной культуры Оренбургского края (XVIII-XX вВ.). Оренбург: ФГУП ИПК «Южный Урал», 2004. 632 с.

18. Хавторин Б.П. Музыкальная культура Оренбурга XX столетия. Оренбург: Оренбургское книжное издательство, 1999. 440 с.

19. Шадринская старина. 1999. Краеведческий альманах. / Сост. и отв. ред. С.Б. Борисов. Шадринск: Изд-во Шадр. пед. инст., 1999. 174 с.

(c) Семенов Сергей Владимирович (ssemenov_2001@mail.ru).

Журнал «Современная наука: актуальные проблемы теории и практики» 